\title{
Prehistoric shellfish utilization and settlement systems on western Santa Cruz Island
}

\author{
Michael A. GLASSOW ${ }^{1, *}$ \\ ${ }^{1}$ Department of Anthropology, University of California, Santa Barbara, CA 93106-3210
}

\begin{abstract}
Archaeologists generally have not taken advantage of the distinctive characteristics of assemblages of shellfish remains from prehistoric sites to gain information about movement of people between sites within their territory. I attempt to demonstrate this potential through analysis of shell assemblages obtained through small-scale test excavation at 2 archaeological sites in the interior of Santa Cruz Island: CA-SCRI-796 in the western sector of the island and CA-SCRI-758 at an upland location in the central sector. An aspect of the data analysis focused on strata containing an abundance of red abalone shells, dating sometime between 3700 and $3350 \mathrm{cal} \mathrm{BC}$ at CA-SCRI-796 and sometime between 4900 and $4325 \mathrm{cal} \mathrm{BC}$ at CA-SCRI-758. Also considered are assemblages from later strata at CA-SCRI-758, dating between 2600 and 1600 cal BC. Alternative hypotheses to account for the differences between the sites in proportions of shellfish taxa represented are the following: differences in proportional abundances of taxa at the localities where site inhabitants collected shellfish, changes over time in the character of shellfish communities, different distances of the sites from sources of shellfish, and variation in the intensity of shellfish collecting. The first alternative appears to account for most of the differences between assemblages, thus providing information about the geographic extent of settlement systems.
\end{abstract}

Resumen._En general, los arqueólogos no han aprovechado las características distintivas de los ensambles de vestigios de moluscos en sitios prehistóricos, para informar sobre el desplazamiento de individuos hacia diversas áreas dentro de su territorio. Intentamos demostrar su potencial mediante el análisis de los ensambles de moluscos obtenido a través de pruebas de excavaciones a pequeña escala, en dos zonas arqueológicas en el interior de la isla Santa Cruz: CA-SCRI-796 en el sector occidental de la isla y CA-SCRI-758 en una meseta en el sector central. Un aspecto del análisis de los datos se centró en los estratos que contienen gran cantidad de conchas de abulón rojo, que en ocasiones datan de entre los años 3700 y 3350 cal A.C. en CA-SCRI-796 y entre los años 4900 y 4325 cal A.C. en CA-SCRI-758. Así mismo, consideramos ensambles provenientes de capas posteriores en CA-SCRI-758, que datan de entre los años 2600 y 1600 cal A.C. Las hipótesis alternativas para explicar las diferencias entre los sitios, en cuanto a la proporción de taxones de moluscos que presentan los ensambles son: (1) diferencias en la cantidad proporcional de taxones en las localidades donde los habitantes del lugar recolectaron moluscos, (2) cambios en el tiempo en las características de las comunidades de moluscos, (3) variación en la distancia entre los sitios de procedencia de los moluscos y (4) variación en la intensidad de colecta de moluscos. La primera alternativa parece explicar la mayoría de las diferencias entre los ensambles, proporcionando así información sobre la extensión geográfica de los sistemas de asentamiento.

Marine shellfish were an important food resource for people throughout the known prehistory of Santa Cruz Island. Many archaeological sites at the coast contain huge accumulations of shells, and sites in the remotest reaches of the interior also contain substantial quantities. Although archaeologists have characterized shell assemblages at many sites on the island, they have devoted little attention to identifying the differences between assemblages and the meaning of those differences, particularly with regard to patterns of human movement between sites for resource acquisition and for social interaction, that is, what commonly are called settlement systems (Binford 1980). In this paper I consider differences in shell assemblages obtained from 2 interior sites on the island, CA-SCRI-758 and CASCRI-796 (Fig. 1), and I evaluate hypotheses that might account for these differences. I focus on a period between 4700 and $3500 \mathrm{cal} \mathrm{BC}$, but because CA-SCRI-758 also contains deposits dating between 2600 and $1600 \mathrm{cal}$ BC, I also consider this time interval as well.

*Corresponding author: glassow@anth.ucsb.edu 


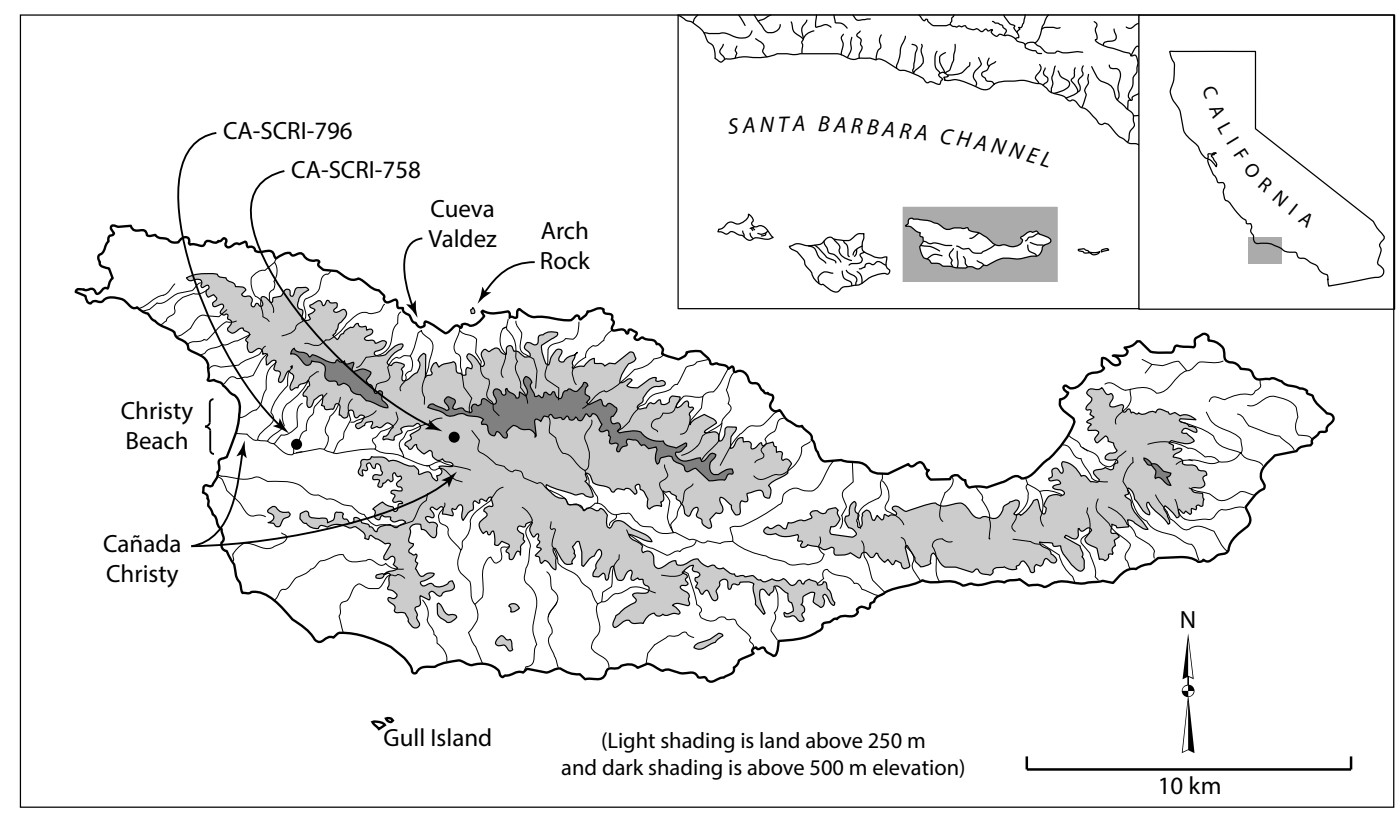

Fig. 1. Map of Santa Cruz Island showing locations of archaeological sites and place names mentioned in the text.

In 2013 I carried out small-scale test excavations at the 2 sites to learn more about the nature of settlement systems during the period between 5000 and 3300 cal $\mathrm{BC}$, when red abalone (Haliotis rufescens) was a prominent constituent of shell assemblages at sites in the western sector of the island. My previous investigations of archaeological deposits with noticeable quantities of red abalone shells, which I termed red abalone middens (Glassow 1993), were at sites at or very near the coast (Glassow 2005, Glassow et al. 2008). In the 2013 project I wished to acquire information about the nature of interior resources that the island's inhabitants were utilizing and more generally the nature of island settlement systems during this time period. As is the case with most red abalone middens on the island, those at the 2 sites are buried under later deposits and consequently were discovered fortuitously.

CA-SCRI-758 is located in the central interior area of the island at an elevation of $445 \mathrm{~m}$ above sea level (Fig. 1). Heather Thakar and I discovered the red abalone midden at this site in 2011 during bucket-augering undertaken to identify deposits at the head of the Cañada Christy watershed that would relate to her dissertation project. The 3 radiocarbon dates obtained for the auger sample (Table 1) revealed that all deposits were too early for the dissertation project, but the lowermost deposits in the sample contained red abalone shells, and the associated radiocarbon date fell within the range of dated red abalone middens elsewhere on the island. The deposits cover the top of a knoll along a ridge descending southward from the northern mountain ridge on the island. The site is $30 \times 50 \mathrm{~m}$ in area, discounting the midden that has eroded downslope to the east, but deposits over most of the site area appear to be $<20 \mathrm{~cm}$ in depth. The area of deposits more than $\sim 50 \mathrm{~cm}$ thick appears to be no more than $20 \mathrm{~m}$ in diameter. Stratum IV, 46-60 $\mathrm{cm}$ below surface in the column sample, is the red abalone midden.

CA-SCRI-796 consists of a midden stratum formerly visible along the western bank of a stream course, located within the lower section of a northern tributary of Cañada Christy and about $1.8 \mathrm{~km}$ from the coast (Fig. 1). Two of my colleagues and I discovered CA-SCRI796 during a 2001 reconnaissance. In 2002, Ballantyne (2006:18) tested this midden in the context of a soils study. At the time of Ballantyne's investigation, the deposits were visible along a $10-\mathrm{m}$ breadth of the bank. However, no effort was made to clear slough along the bank to determine the full extent. Also, because the archaeological deposits 
TABLE 1. Radiocarbon dates for CA-SCRI-758 and CA-SCRI-796 ${ }^{\text {a }}$. All dates were calibrated or recalibrated using Calib 7.0.1 and a delta $\mathrm{R}$ marine reservoir correction of $225 \pm 35$.

\begin{tabular}{|c|c|c|c|c|}
\hline Provenience ${ }^{b}$ & $\begin{array}{c}\text { Conventional } \\
\text { date }\end{array}$ & $\begin{array}{c}\text { Cal date BC } \\
1 \text { sigma }\end{array}$ & $\begin{array}{c}\text { Cal date BC } \\
2 \text { sigma }\end{array}$ & Lab number \\
\hline \multicolumn{5}{|l|}{ CA-SCRI-796 } \\
\hline $4-15 \mathrm{~cm}$, Stratum II & $5324 \pm 33$ & $3607-3469$ & $3618-3374$ & DAMS-6360 \\
\hline $15-25 \mathrm{~cm}$, Stratum III & $5714 \pm 30$ & $3977-3857^{\mathrm{c}}$ & $4024-3789$ & DAMS-6752 \\
\hline $25-35 \mathrm{~cm}$, Stratum III & $5948 \pm 34$ & $4260-4116$ & $4307-4046$ & DAMS-6361 \\
\hline $34-45 \mathrm{~cm}$, Stratum IV & $5840 \pm 27$ & $4117-3987^{c}$ & $4199-3956$ & DAMS-6753 \\
\hline KB Cultural Stratum $1^{\mathrm{d}}$ & $5010 \pm 70$ & $3256-3002$ & $3320-2903$ & Beta-187391 \\
\hline KB Cultural Stratum 2, Strata II-III & $5580 \pm 60$ & $3861-3687^{c}$ & $3929-3636$ & Beta- 185925 \\
\hline Upper portion, Stratum II & $5387 \pm 38$ & $3626-3523$ & $3692-3451$ & DAMS-2531 \\
\hline Lower portion, Stratum III & $5920 \pm 36$ & $4226-4079$ & $4293-4019$ & DAMS-2532 \\
\hline \multicolumn{5}{|l|}{ CA-SCRI-758 } \\
\hline $0-10 \mathrm{~cm}$, Stratum I & $3967 \pm 29$ & 1782-1643 & $1865-1605$ & DAMS-6754 \\
\hline $10-20 \mathrm{~cm}$, Stratum I & $4686 \pm 31$ & $2772-2614^{c}$ & $2847-2561$ & DAMS-6755 \\
\hline $20-30 \mathrm{~cm}$, Stratum II & $4493 \pm 28$ & $2489-2348$ & $2559-2290$ & DAMS -6756 \\
\hline $30-40 \mathrm{~cm}$, Stratum II & $4523 \pm 35$ & $2553-2413$ & $2613-2314$ & DAMS-6362 \\
\hline $40-50 \mathrm{~cm}$, Stratum III & $6299 \pm 28$ & $4606-4482$ & $4673-4441$ & DAMS-6757 \\
\hline $50-60 \mathrm{~cm}$, Stratum IV & $6400 \pm 34$ & $4724-4593$ & $4786-4530$ & DAMS-6363 \\
\hline $50-60 \mathrm{~cm}$, Stratum IV & $6347 \pm 30$ & $4666-4542$ & $4715-4478$ & DAMS-6364 \\
\hline $60-70 \mathrm{~cm}$, Stratum V & $6436 \pm 30$ & $4773-4651$ & $4827-4575$ & DAMS-6365 \\
\hline $70-80 \mathrm{~cm}$, Stratum VI & $6497 \pm 28$ & $4828-4712$ & $4903-4666$ & DAMS-6758 \\
\hline Auger, $\sim 0-12 \mathrm{~cm}$, Stratum I & $4560 \pm 40$ & $2589-2449$ & $2685-2352$ & Beta-298684 \\
\hline Auger, $\sim 33-43 \mathrm{~cm}$, Strata II-III & $4550 \pm 30$ & $2567-2449$ & $2650-2365$ & Beta-298685 \\
\hline Auger, $\sim 55 \mathrm{~cm}$, Stratum IV & $6200 \pm 40$ & $4489-4365$ & $4561-4325$ & Beta-298686 \\
\hline
\end{tabular}

west of the bank are covered with $1 \mathrm{~m}$ of stream deposits, its extent in that direction is unknown. The red abalone midden stratum at the bank extends between 4 and $18 \mathrm{~cm}$ below the top of the deposits, and below it are lower-density deposits extending to a depth of $55 \mathrm{~cm}$ below the top of the deposits. Not excavated was another midden stratum lacking red abalone shells that is visible on the stream bank $50 \mathrm{~cm}$ above the red abalone midden. Ballantyne (2006:42) obtained a radiocarbon date for this stratum, which indicated that it dates 300-400 years later in time (Table 1).

\section{Methods}

A test unit $0.5 \times 1.0 \mathrm{~m}$ in area was excavated at each site, and material collected from each definable stratum was kept separate. All deposits were sifted through a $1 / 8$-inch (3.2-mm) mesh screen, and everything retained by the screen was brought to the University of California, Santa Barbara (UCSB), for processing. The unit at CA-SCRI-758 was located $30 \mathrm{~cm}$ from the 2011 auger test. At CA-SCRI-796, the red abalone midden was not visible in 2013 due to aggradation of the streambed;
$35 \mathrm{~cm}$ of stream gravels had covered the midden. Consequently, an area larger than the size of the test unit had to be cleared of the gravels to create space for the unit and to define the extent of the midden into the stream channel. Initially, the unit was divided into two $50 \times 50-\mathrm{cm}$ sections, and only the northern half was excavated to the base of the deposits. The main stratum of deposits, the 4- to $18-\mathrm{cm}$ level, was excavated in both halves. A column sample $20 \times 20 \mathrm{~cm}$ in area was obtained from the walls of the 2 halves, divided between the two in separate depth intervals. The main stratum, 4-18 cm below the top of the deposits, is the only one considered here.

The analysis presented here is based on data derived from the column samples. At UCSB, the column samples were processed by flotation, and the analysis of shell taxon variability was based on heavy-fraction portions larger than $1 / 8$ inch, but only material larger than $1 / 4$ inch $(6.4 \mathrm{~mm})$ was considered for this paper, given that data from the shell fragments smaller than $1 / 4$ inch would add little to this analysis. The remainder of the collections, including the $1 / 8$ - to $1 / 4$-inch portions, was 


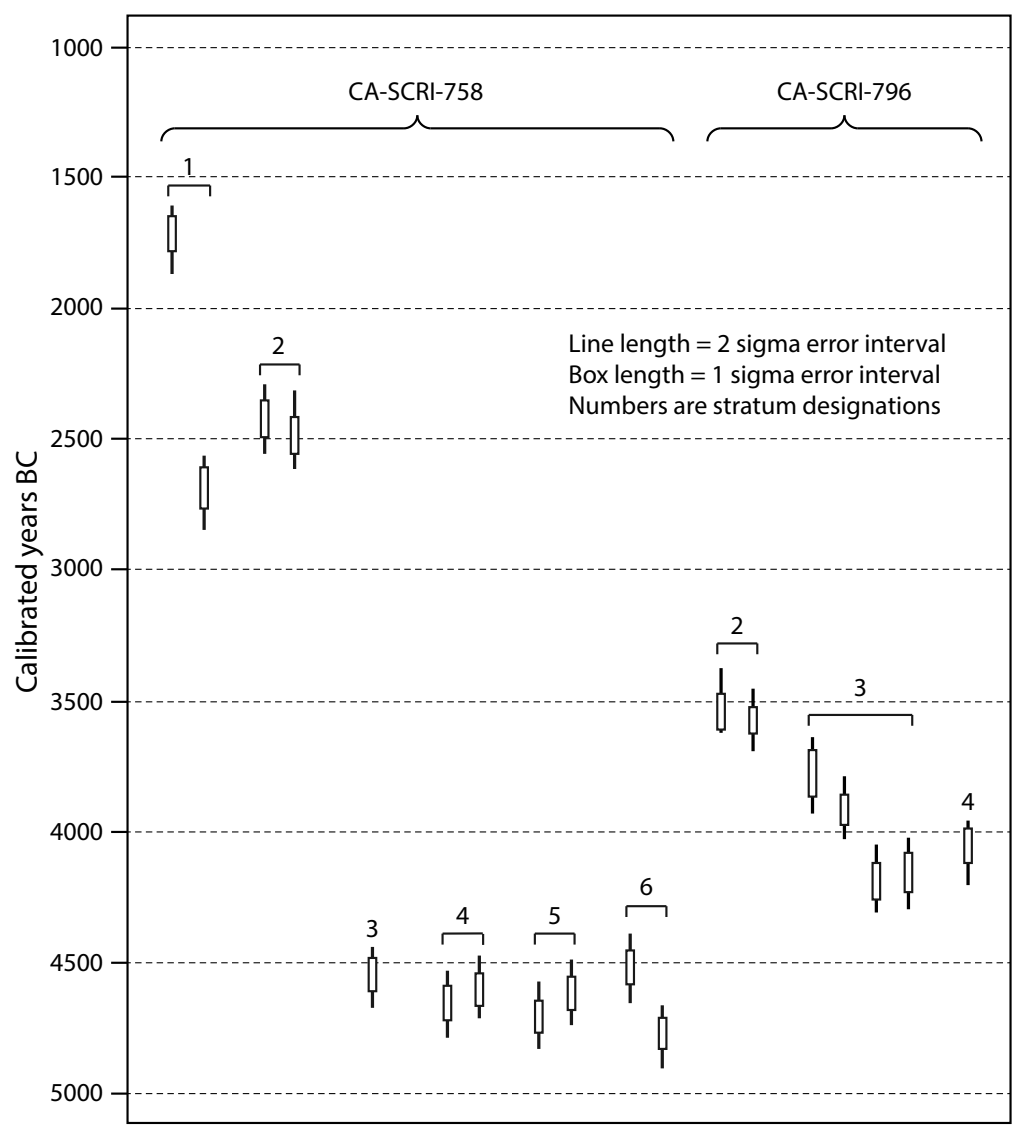

Fig. 2. Distribution of calibrated radiocarbon dates for CA-SCRI-758 and CA-SCRI-796.

processed in various ways to produce data not considered in this paper.

To investigate variation in the size of California mussels (Mytilus californianus) the site inhabitants collected, 2 different measures served as proxies for mussel valve length: umbo thickness and anterior adductor muscle scar length. Both measures correlate strongly with valve length (Hamilton 1992, Campbell and Braje 2015:170, Glassow et al. 2016:35), although each proxy has advantages and disadvantages.

\section{Chronology}

The chronology of occupation at the 2 sites is based on 12 radiocarbon dates for CA-SCRI-758 and 8 radiocarbon dates for CA-SCRI-796 (Table 1). All dates were derived from individual marine shells. Those for CASCRI-758 fall into 3 clusters (Fig. 2). The earliest, between 4903 and 4325 cal BC, pertains to the red abalone midden and lowdensity underlying deposits-Strata 4 through 6 (strata as defined during the unit excavation). The date intervals for just Stratum 4, the red abalone midden, spans a period of 460 years. Strata 5 and 6 may be slightly earlier than Stratum 4, but a larger number of dates would be necessary to determine this. A second cluster, pertaining to Strata 1 through 3, spans a period between 2847 and 2314 cal BC, discounting one Stratum 3 date that falls within the earlier time interval and is likely the result of mixing of deposits. The youngest cluster consists of just one date from the upper portion of Stratum 1, having a 2-sigma interval of 1805-1605 cal BC. Most likely no more than the uppermost $10 \mathrm{~cm}$ of deposits pertains to this time interval. The densest midden stratum at CA-SCRI-796, 4-18 cm below the top of the archaeological deposits, dates to $\sim 3500$ 


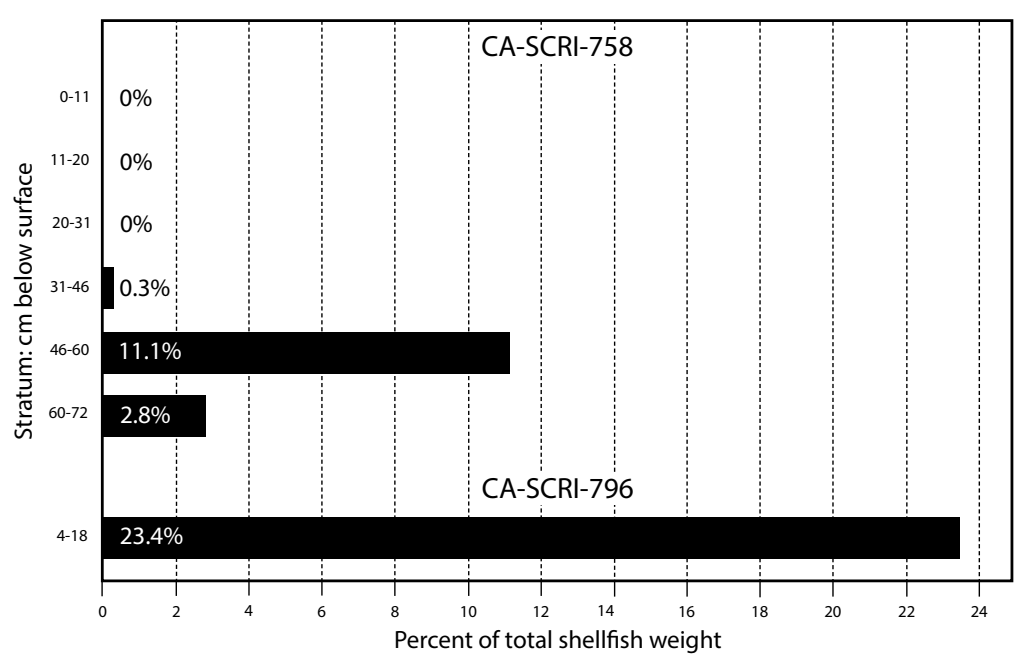

Fig. 3. Red abalone shell weight percentages of total shell weight by stratum at CA-SCRI-758 and CA-SCRI-796.

cal BC and appears to be $\sim 400$ years later than the basal midden deposits containing a much lower density of shell and other remains (Fig. 2). Two dates, however, fall within the 400-year interval between the earlier and later dates, implying at least some occupation at the site during this time.

Although the current number of radiocarbon dates provides useful information for understanding the chronology of occupation at both sites, many more would be necessary to ascertain continuity and discontinuity of occupation, in part because of the inherent error associated with each date. It is possible, for instance, that site occupation was sporadic within the period represented by a date cluster. Also, additional dates may reveal occupation during times not represented by the dates currently available.

\section{Abalone Abundance}

The abundance of red abalone shells within the 2 red abalone middens, as measured by their weight relative to the total weight of shell fragments in the $\geq 1 / 4$-inch size range (Fig. 3), is higher than at other investigated red abalone middens on the island, which typically have no more than $1 \%$ to $2 \%$ of the total weight of shellfish remains (Glassow 2005:26). However, one of the largest coastal middens, at CA-SCRI-333, has concentrations of red abalone shells up to $80 \%$ of the shellfish remains by weight (Gamble 2017:444).
Considering that the other investigated red abalone middens are adjacent to the coast, the higher percentages at CA-SCRI-758 and CA-SCRI-796 appear anomalous. A possible reason for the lower percentages in coastal red abalone middens is the destruction of large portions of the site deposits due to sea cliff erosion, with the remaining marginal deposits containing lower proportions. However, the low percentage at CA-SCRI-109 on the south coast of the island may result from the site's easterly location on the south coast, where sea surface temperatures are warmer than along the coastline in the western sector of the island and where red abalones therefore were likely less accessible given their occurrence in deeper waters (Glassow 1993, Glassow et al. 1994).

The percentage of red abalone shell within the CA-SCRI-796 red abalone midden is more than twice that within the red abalone midden at CA-SCRI-758. Three hypotheses may be proposed to account for this difference. First, the difference may be the result of a shift in red abalone availability over time due to fluctuation in ocean water temperature. At the time site inhabitants were depositing red abalone shells at CA-SCRI-758, red abalone may have been living in deeper water due to warmer water temperatures, and therefore were less accessible than later, when CASCRI-796 was occupied. The sea surface temperature record reported by Kennett (2005:66) indicates that the beginning of the period of occupation at CA-SCRI-796 was an 
interval of very cool waters, but during the later half of the period, waters had warmed considerably. However, the oxygen-isotope analysis of calcite samples from archaeological shells collected at CA-SCRI-109 (Glassow et al. 2012:2581), spanning most of the period of CA-SCRI-796 occupation, indicates that the waters remained cooler than at present throughout essentially all of the period of CA-SCRI-796 occupation. The red abalone midden at CA-SCRI-758 was deposited during a period of moderately warm to moderately cool waters according to Kennett's sea surface temperature record. A case could be made that waters were generally warmer during the period of the red abalone midden at CA-SCRI-758, thus supporting the hypothesis. However, the discrepancies between Kennett's record and the record derived from the CA-SCRI-109 mussel shells suggest that more data are needed for greater confidence.

The second hypothesis proposes that the difference between the 2 sites is related to varying distances of the sites from a coastal locale where red abalone could be collected. Greater effort was required to transport red abalone in-the-shell to CA-SCRI-758, given its greater distance from the coast and its high elevation. On the basis of the distribution of most red abalone middens in the western sector of the island (Glassow 2015), most likely the closest locale to both sites would have been the rocky shoals beyond the north end of Christy Beach. CA-SCRI-758 is $6.6 \mathrm{~km}$ from this locale, and CA-SCRI-796 is $2.4 \mathrm{~km}$ (straight-line distances). The next closest locality from which CA-SCRI-758 occupants could obtain red abalone (as well as mussel and pismo clam [Tivela stultorum]) would have been on the south coast at Punta Arena (Glassow et al. 2008), a 7.0-km straight-line distance from CA-SCRI-758, but the intervening terrain is more rugged than down the length of Cañada Christy to the shoreline. CA-SCRI-758 occupants probably were not obtaining red abalone along the coast nearest to the site, that is, directly north of the site along the island's northern coastline. The steep and narrow intertidal zone and adjacent submerged substrate are not ideal habitat for abalone.

Interestingly, the distances between both sites and the red abalone source are greater than the approximately $2-\mathrm{km}$ threshold for economical transport of a $15-\mathrm{kg}$ load of unshucked red abalone, as calculated by Jazwa et al. (2015:40). The differing travel distances from the closest red abalone source may partially account for the different percentages of red abalone shells at the 2 sites, but why did the site inhabitants not shuck the abalones before transport, given the distances they had to be transported? The analysis of Jazwa et al. (2015:40) revealed that the travel distance threshold for transporting a much larger load of unshucked abalone, $36 \mathrm{~kg}$, would be $4.33 \mathrm{~km}$, and presumably the distance threshold would be even longer if an even larger load was distributed among several carriers. Also, unshucked abalone meat would remain reasonably fresh longer than if just the meat were brought to the site, but this reasoning assumes that not all of the abalone were consumed immediately upon arrival at a site; if they were, then maintaining freshness would not be an issue.

The third hypothesis concerns the social context of abalone consumption and the functional position of each site within a settlement system. Red abalones may not have been an everyday food, instead being collected and consumed in the context of special social occasions such as feasting events, as proposed by Gamble (2017:443) to have occurred at CASCRI-333. However, neither CA-SCRI-758 nor CA-SCRI-796 yielded artifacts or features indicative of special social activities, and the small size of the midden at CA-SCRI-758 implies occupation by a relatively small kin group. Nonetheless, the red abalone midden at CA-SCRI-758 is distinctive in comparison to others on the island in that essentially all the shell, including the red abalone shell, is burned and is within a matrix of ashy soil. Furthermore, the diversity of minor species within this stratum is anomalously low, especially in light of the relatively high density of shell in this stratum. As will be discussed below, these characteristics may be the result of nonroutine food consumption activities perhaps associated with social events.

\section{Acorn Barnacle Abundance}

Acorn barnacle (Balanus spp.) shells are considerably more abundant at CA-SCRI758 than at CA-SCRI-796 (Fig. 4). Abundance of acorn barnacles was measured as 


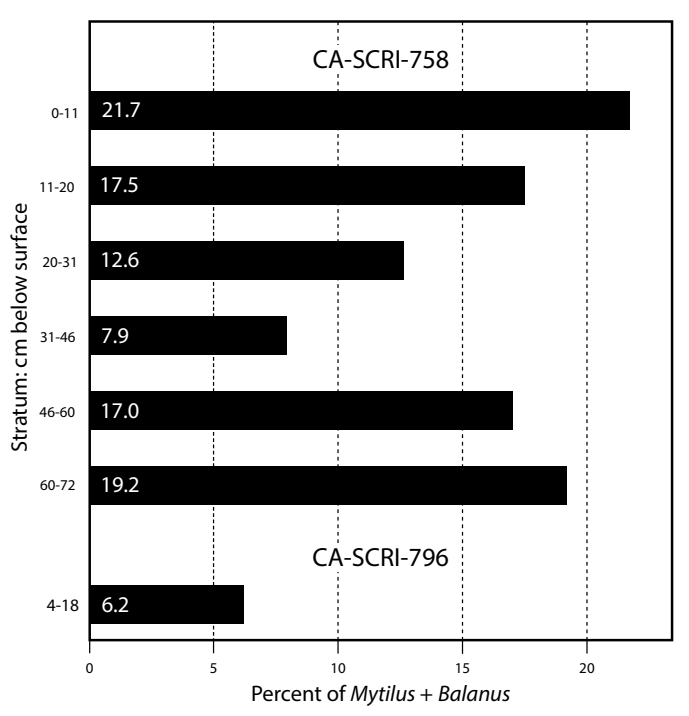

Fig. 4. Balanus spp. shell percentages of the combined weight of Balanus spp. and Mytilus californianus shell by stratum at CA-SCRI-758 and CA-SCRI-796.

the percentage of the total weight of mussel and acorn barnacle shell (excluding other shellfish species). Barnacle shell fragments with intact bases typically exhibit negative impressions of mussel shells, implying that they were brought to the sites attached to mussel shells and probably were not purposefully collected. It follows, therefore, that inhabitants of CA-SCRI-758 collected mussels at locations where barnacles either were more frequently attached to mussels or were larger and more likely to be included in shell assemblages compared to locations where CASCRI-796 inhabitants collected mussels.

Even greater abundances of acorn barnacles are present in some strata at CA-SCRI619/620, located $1.8 \mathrm{~km}$ from CA-SCRI-758 on the north slope of the island (Gill 2015:153, 177). Assuming that inhabitants of both sites would have collected mussels from the nearest portions of the island's coastline, the north coast in the vicinities of Cueva Valdez and Arch Rock is the most likely possibility. In contrast, inhabitants of CA-SCRI-796 most likely collected mussels at either end of Christy Beach where rocky intertidal habitats exist. Blanchette et al. (2006:696) report that mussels and barnacles cover larger proportions of the intertidal zone and that mussels grow faster at Prisoners Harbor on the north coast than along the coastlines of the western portion of the island. Considering that waters along much of the north coast of the island are warmer than along the island's western sector and that water temperature is a major factor affecting mussel and barnacle growth rate and abundance (Blanchette et al. 2006), the Prisoners Harbor data may be generally representative of the north coast locations farther west where CA-SCRI-758 inhabitants presumably collected shellfish. However, other factors not yet understood may affect productivity and size of barnacles at different locations around the island. In any case, the difference between the 2 sites in the abundance of barnacles relative to mussels probably reflects differences in the nature of intertidal shellfish communities between the western sector coastlines and the northern coastline.

\section{Proportional Differences in Minor Shellfish Species}

Proportional differences between sites in species represented in shell assemblages may be the result of 3 basic factors: differences in the abundance of shellfish within the foraging ranges from sites, differences in intensity of shellfish collecting by each site's inhabitants, and differences in proportional abundance of shellfish taxa around the perimeter of the island. To complicate matters, these factors may vary over time.

The first factor, shellfish abundance within a site's foraging range, concerns the overall amount of utilizable shellfish available to a site's inhabitants. Near some sites, for instance, accessible coastline for shellfish collecting may be limited due to seacliffs or narrowness of the intertidal zone, whereas near other sites are continuous stretches of relatively flat-lying bedrock forming broad intertidal zones. In the latter situation, a population of a given size would be able to focus more on high-return species and the largest individuals.

Regarding the second factor, archaeologists long have recognized the influence of intensity of shellfish collecting on shell assemblage composition (e.g., Glassow 1992:127, Braje et al. 2007, 2012, Braje et al. 2011:277). Increasing shellfish collecting intensity, for example, may be due to the increasing size of the group occupying a site, or more generally the island's population, assuming that inhabitants did not shift to other sources of protein 
TABLE 2. Weights (g) of red abalone, acorn barnacle, and minor taxa by stratum at CA-SCRI-758 and CA-SCRI-796.

\begin{tabular}{|c|c|c|c|c|c|c|c|c|}
\hline \multirow[b]{2}{*}{ Taxon } & \multicolumn{7}{|c|}{ CA-SCRI-758 strata (cm below surface) } & \multirow{2}{*}{$\frac{\text { CA-SCRI-796 }}{4-18}$} \\
\hline & $0-11$ & $11-20$ & $20-31$ & $31-46$ & $46-60$ & $60-72$ & Total & \\
\hline Acmaea spp. & 0.12 & 0.66 & - & - & - & - & 0.78 & - \\
\hline Balanus spp. & 68.58 & 104.22 & 36.97 & 31.55 & 71.39 & 68.15 & 380.86 & 10.85 \\
\hline Chiton & 0.28 & 0.06 & - & - & - & - & 0.34 & 0.76 \\
\hline Crab & 0.14 & - & - & - & - & - & 0.14 & - \\
\hline Crepidula spp. & - & 2.24 & - & 0.07 & - & - & 2.31 & 0.05 \\
\hline Gastropod, small & 0.20 & 0.92 & - & - & - & - & 1.12 & - \\
\hline Haliotis crachrodii & - & - & - & - & - & - & - & 3.1 \\
\hline Haliotis rufescens & - & - & - & 1.32 & 59.24 & 10.9 & 71.46 & 68.26 \\
\hline Limpets, small & - & - & 0.22 & 0.08 & - & - & 0.3 & - \\
\hline Megastraea undosa & - & - & - & - & - & 10.37 & 10.37 & 15.92 \\
\hline Olivella biplicata & - & - & - & 0.23 & - & - & 0.23 & - \\
\hline Neverita lewisii & - & 3.92 & - & - & - & - & 3.92 & - \\
\hline Pollicipes polymerus & 0.93 & 2.24 & 0.38 & 1.47 & 1.75 & 0.94 & 7.71 & 0.14 \\
\hline Mytilisepta bifurcata & - & - & - & 0.09 & - & - & 0.09 & 3.24 \\
\hline $\begin{array}{l}\text { Thylacodes } \\
\text { squamigerus }\end{array}$ & - & 0.36 & - & 0.47 & 0.76 & - & 1.59 & 0.75 \\
\hline $\begin{array}{l}\text { Strongylocentrotus } \\
\text { purpuratus }\end{array}$ & 0.11 & 0.19 & - & - & 0.03 & - & 0.33 & - \\
\hline Tegula funebralis & - & - & - & - & - & - & - & 0.97 \\
\hline Tivela stultorum & - & - & - & 2.30 & - & 4.49 & 6.79 & - \\
\hline TOTAL & 70.36 & 114.81 & 37.57 & 37.58 & 133.17 & 94.85 & 488.34 & 104.04 \\
\hline NO. OF MINOR TAXA & 6 & 8 & 2 & 8 & 3 & 3 & & 8 \\
\hline
\end{tabular}

such as fish or sea mammals. With increasing shellfish-collecting intensity, the size and/or abundance of highest-ranked species (with respect to rate of food-value return per unit of collecting/processing effort) eventually would have decreased to a point at which inclusion of, or increased predation on, lowerranked species became economical. Lowerranked species therefore would have become proportionally more important to the diet.

The third factor is variation in shellfish species abundance around the perimeter of the island. This variation is not well documented, although some data exist (Blanchette et al. 2006). Most obvious is the contrast between sandy and rocky shorelines. Pismo clams are available at times along some sandy beaches, whereas a variety of rock-perching species, particularly the California mussel, are available along rocky shorelines. Perry (2005:48; see also Perry and Hoppa 2012) found that sites located near the south coast in the eastern sector of the island contain relatively high proportions of wavy top (Megastraea undosa) shells due to nearby waters that are warmer than those found elsewhere along the island's coast. Similarly, Glassow (1993) and Glassow et al. (1994) proposed that cooler water temperatures prevailing along the coastline of the western sector of the island resulted in greater accessibility to red abalone than would have been the case farther east. The growth rate of particular shellfish species also may be affected by water temperature, and where growth rates are higher, the species could tolerate higher rates of predation (Thakar et al. 2017).

Considering first just the red abalone strata at each site, taxa other than mussels and acorn barnacles are more diverse in the 4-18-cm level at CA-SCRI-796 (8 taxa) than in the 46-60-cm level at CA-SCRI-758 (3 taxa) (Table 2). Despite this difference, the major taxa (acorn barnacle, mussel, red abalone, and nacre fragments) are nearly equal in their contribution to the total shell weight: $91.0 \%$ at CA-SCRI-796 and 91.4\% at CA-SCRI-758. In other words, the degree of dependence on minor taxa is not the result of decreased abundance of mussel. Within the red abalone stratum at CA-SCRI-796, wavy top and black abalone (Haliotis cracherodii) dominate the minor species, each being $>1.0 \%$. However, within the red abalone stratum at CA-SCRI758 , all the minor species are $<1.0 \%$, and wavy top, black abalone, platform mussel (Mytilisepta bifurcata), and black turban (Tegula funebralis) are absent.

One factor accounting for the differences between the 2 red abalone middens likely is 

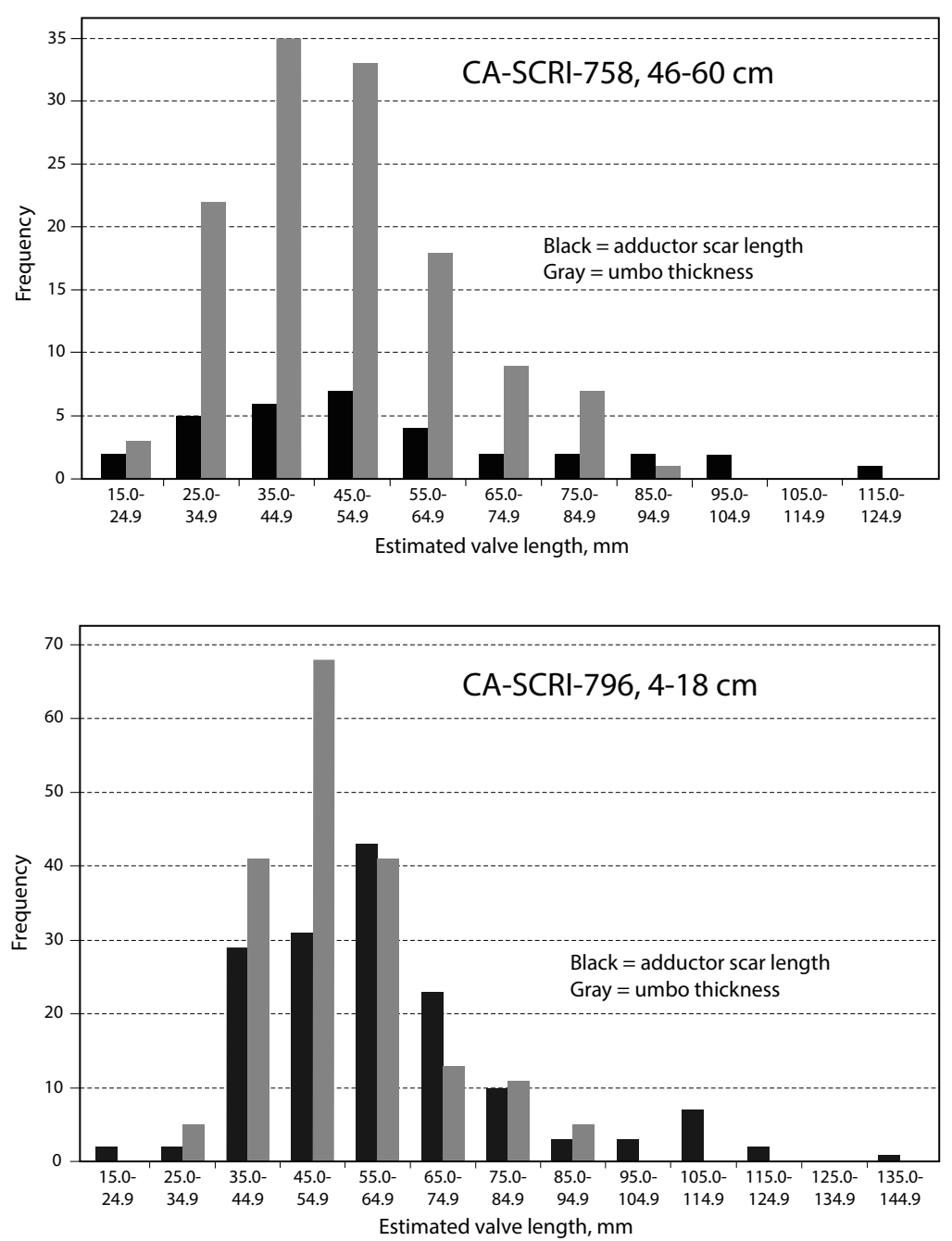

Fig. 5. Frequency distributions of Mytilus califorianus valve lengths within red abalone midden strata at CA-SCRI-758 and CA-SCRI-796, based on 2 proxies of valve length (adductor scar length and umbo thickness).

differences in the nature of shellfish communities from which occupants of the 2 sites collected. Although these differences are not documented, the CA-SCRI-796 assemblage is similar to those of nearby sites, including CASCRI-574 (Glassow 2014:126) and CA-SCRI568 (Thakar 2014:420). Predation intensity, whether the result of differences in the number of site occupants or the abundance of shellfish within each site's foraging range, appears not to have been a factor; if it were, the more diverse minor species at CA-SCRI796 should be associated with a smaller average mussel size. However, the opposite appears to be the case based on proxy measurements of mussel size (Fig. 5). The intertidal zone along the north coast of the island, where occupants of CA-SCRI-758 likely were obtaining shellfish, is much narrower than would have been available to the occupants of CASCRI-796, particularly northwest of Christy Beach. This difference could account for the smaller size of mussel shells at CA-SCRI-758 but not the diversity of minor taxa.

Most of the other strata at CA-SCRI-758 have a higher diversity of minor species, and as the number of species per $100 \mathrm{~g}$ of shell demonstrates (Table 3), the total amount of shell per stratum is only one factor affecting the variation. Indeed, the red abalone stratum 
TABLE 3. Number, total weight, and normalized number of minor species at CA-SCRI-758.

\begin{tabular}{lccc}
\hline $\begin{array}{l}\text { Stratum } \\
\text { depth }(\mathrm{cm})\end{array}$ & $\begin{array}{c}\text { Number } \\
\text { of taxa }\end{array}$ & $\begin{array}{c}\text { Total shell } \\
\text { weight }(\mathrm{g})\end{array}$ & $\begin{array}{c}\text { Number of taxa } \\
\text { per } 100 \mathrm{~g}\end{array}$ \\
\hline $0-11$ & 6 & 319.4 & 1.88 \\
$11-20$ & 8 & 611.5 & 1.31 \\
$20-31$ & 2 & 293.4 & 0.68 \\
$31-46$ & 8 & 413.9 & 1.93 \\
$46-60$ & 3 & 532.4 & 0.56 \\
$60-72$ & 3 & 386.2 & 0.78 \\
\hline
\end{tabular}

has the second highest shell weight but the lowest number of minor taxa and the lowest number of taxa per $100 \mathrm{~g}$ of shell weight. However, the similarly low number of minor taxa in the 20-31-cm stratum may be partly a result of it having the lowest amount of shell. There is no clear trend over time in the number of taxa per $100 \mathrm{~g}$ of shell weight, given that the largest number of taxa is in the stratum immediately above the red abalone midden. Regarding the taxa present in the strata, no black abalone or black turban shell was identified, but all other taxa present at CA-SCRI796 also are present in the upper strata at CA-SCRI-758.

The lack of obvious chronological trends in minor species diversity does not mean that the variation is not the result of such factors as fluctuation in shellfish abundance in intertidal zones or collecting intensity. Both factors may have fluctuated over time. Assuming that occupants of CA-SCRI-758 collected shellfish during all periods from roughly the same stretch of coastline along the island's northern coastline, fluctuation in shellfish productivity, particularly of California mussel, may have occurred because of fluctuation in such environmental factors as sea surface temperature. No data are currently available to evaluate this possibility. Alternatively, collecting intensity may have varied over time, which would be expected if the site was occupied by groups of varying size over time. Fluctuation in collecting intensity may be measured by fluctuation in mussel length: the diversity of minor species would be expected to inversely correlate with mussel length. Data presented in Fig. 6 reveal that no obvious correlation exists.

\section{Conclusions}

Inland sites throughout the island often contain abundant shell, giving clear evidence of the importance of shellfish as a reliable food resource, particularly of protein. Mussels were by far the most popular shellfish because of their relatively large size and abundance, and probably no location on the island is more than a 2-h walk to a coastal locality where mussels and other shellfish could be collected. A basic objective of the analysis presented above was to discern aspects of settlement systems based on the characteristics of shell assemblages-that is, the variety of species present and their proportional abundance. Proportions of species other than mussel, including species that were incidentally brought to the site attached to mussels and other marine food resources, may be most useful in this regard.

As discussed above, many of the differences between the CA-SCRI-758 and CASCRI-796 shell assemblages likely were the result of shellfish being collected at different locations along the island's coast, given that the proportional abundance of some species may vary significantly from one intertidal locality to another. These differences are determined by a variety of factors such as the physical nature of the intertidal zones (e.g., their breadth), water temperature, and surf characteristics. Differences among species represented in shell assemblages from different sites may therefore provide clues to the section of the coast along which site inhabitants collected shellfish. If this can be inferred with reasonable confidence, then something may be said about the particular area of the island over which a site's population ranged to acquire food and other resources. Furthermore, if other sites within this area are known to be contemporaneous, then inferences may be developed about the movement of a group of people between sites and the kinds of resources nearby that may have been utilized.

The presence of red abalone shells and the combination of minor shellfish species represented in the shell assemblage at CA-SCRI758 indicate that the site's occupants acquired shellfish from 2 separate locations, red abalone most likely coming from the intertidal or shallow subtidal waters north of Christy Beach and pismo clam, represented in one of the strata, from the sandy substrate of Christy Beach. The other shellfish taxa presumably came from the north coast of the island. However, whether the site's occupants acquired 


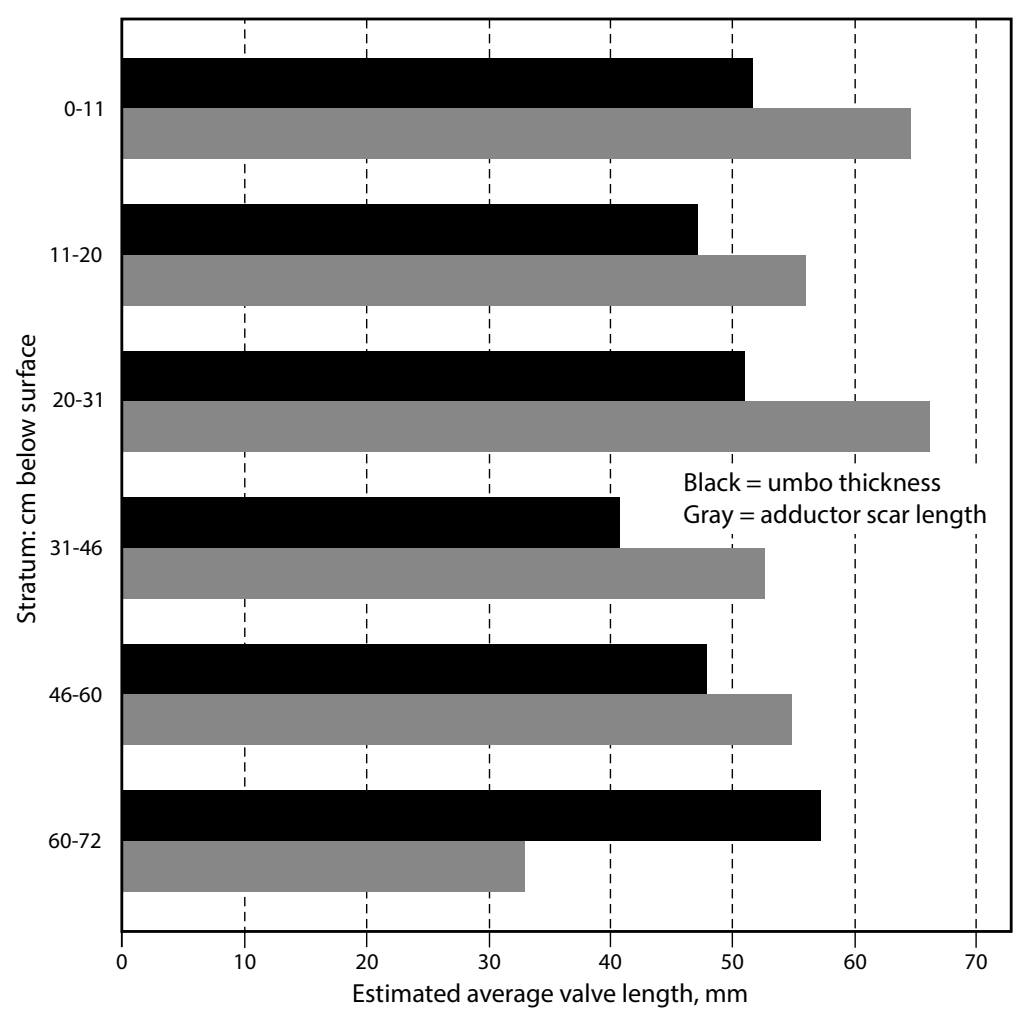

Fig. 6. Estimated average lengths of Mytilus californianus valves within the upper strata at CA-SCRI-758, based on 2 proxies of valve length (umbo thickness and adductor scar length).

the red abalone directly or received them from visitors from the west remains unknown. Even if they acquired red abalone directly, this may not have been a regular activity, perhaps occurring only a few times a year or at even greater intervals of time.

The later occupation of CA-SCRI-758 overlaps that at CA-SCRI-619/620, located on the other side of the mountain ridge north of the site. Although the proportional abundance of shellfish species represented in the shell assemblage is not available, acorn barnacle shells are also unusually abundant at this site (Gill 2015:153, 177). Beginning around 2600 BC, these 2 sites may have been linked within a settlement system that encompassed the vicinities of these 2 sites, as well as sites closer to the north coast. However, even during this later occupation, the presence of pismo clam shell in one of the later strata indicates occasional acquisition of shellfish from a sandy beach habitat, probably at Christy Beach to the west.

The shellfish taxa represented in the CASCRI-796 shell assemblage appear to have been derived exclusively from rocky intertidal zones north and/or south of the Christy Beach. The assemblage is similar to those at other sites in the lower Cañada Christy watershed (Glassow 2014:126, Thakar 2014:403, 412, $420)$ in that acorn barnacle occurs in moderate amounts compared to CA-SCRI-758 and in that black abalone and black turban shells are present. Both sites, as well as many other inland sites, may have been occupied to take advantage of locally available plant food resources, particularly blue dicks (Dichelostemma capitatum) corms (Gill 2014). The location of CA-SCRI-796 on a stream terrace to the east of higher land has the added advantage of protection from wind.

As discussed earlier, it is intriguing that occupants of the 2 sites made the effort to transport unshucked red abalone to these interior sites. The 2 proposed explanations presented above deserve additional attention with regard to their implications for understanding the structure of settlement systems. The first posits that shellfish collectors wished 
to keep the red abalone relatively fresh for several days by transporting them in-the-shell to an inland habitation site. If carriers of the red abalone transported relatively small loads of red abalone, and if this shellfish was collected for consumption within hours after returning to a residential base, shucking would make sense as Jazwa et al. (2015) argued, but if large loads were transported and if much of the consumption was to take place days after arrival, it would make sense to expend the additional effort to transport unshucked abalones and keep them in a cool, ideally damp location until consumed. If the latter scenario in fact was the case, the lower proportions of red abalone in shell assemblages at relatively small coastal sites in the western sector of the island may not be the result of the loss of major portions of the deposits at these sites to seacliff and gully erosion, as proposed earlier. Instead the lower proportions may be the result of transport of many of the collected red abalone to inland sites. While occupants resided at the coastal sites from which red abalone was collected, California mussel would have been the principal shellfish consumed, but some red abalone also would have been consumed. Short-term storage of perishable foodstuffs is not a popular consideration among archaeologists, but it is a possibility worth considering when attempting to account for the transport of bulky and inedible parts of animal and plant foods over long distances.

The other explanation offered above is that red abalone may not have been collected and transported inland for routine food consumption, but instead for social events, much as certain foods consumed in the United States today have a major role in holiday feastingturkey being an obvious example. However, red abalone also may have been consumed as a routine food, as is turkey today. In other words, for certain social events, consumption of red abalone may have had symbolic value of some sort in addition to nutritional value, and site inhabitants may have been willing to expend inordinate effort acquiring and transporting red abalone to sites as far from the source as CA-SCRI-758. Both this site and CA-SCRI-796 may have been locations where distinct social groups (e.g., extended families) periodically gathered not only to feast on red abalone but also to exchange items and information and find mates. Some sites may have served this role almost exclusively, while others were established residential bases. CA-SCRI-758 is on a saddle ridge between 2 major watersheds on the island, Cañada Christy to the west and the Central Valley to the east, a location that would be ideal as a meeting place for people living in the central and eastern portions of the island and people living in the western sector.

Developing and testing hypotheses to elucidate the nature of settlement systems of hunter-gatherers who occupied multiple sites over the course of a year has been a significant challenge for many decades. Yet patterns of mobility between a set of sites that were regularly inhabited for variable lengths of time or visited briefly just a few times by a distinct social group are fundamental to understanding how the group adapted to the environment and related to neighboring groups. Elucidating settlement systems is a challenging enterprise, given that ethnography tells us that they can vary from one year to the next and in general have a great deal of flexibility depending on year-to-year variation in resource availability and other factors (e.g., Steward 1938, Brumbach and Jarvenpa 1997). Indeed, models of settlement systems proposed by archaeologists tend to be simplistic because they do not adequately incorporate this flexibility. Only recently have a few archaeologists begun to confront the complexity and flexibility of prehistoric settlement systems (e.g., Jazwa et al. 2015).

An important approach to the study of settlement systems is to ascertain the season or seasons of site occupation based on the presence of faunal and floral remains of seasonally distinctive species or distinctive parts (e.g., Glassow et al. 2008:72-73, Gill 2014). More recently, oxygen isotope analyses of calcite samples obtained from mussel and other bivalve shells have shown promising results (e.g., Kennett 2005:151-153, Jones et al. 2008, Culleton et al. 2009, Braje 2010:108-109, Jew et al. 2014, Thakar 2014:118-138, Jazwa et al. 2015:41-42). Inferences about patterns of mobility between a series of sites also might be based on ascertaining which sites within an area of land, such as a sector of an island or a set of adjacent watersheds, were contemporaneously occupied (e.g., Jazwa et al. 2015:38). The study presented here adds another source 
of relevant information: the presence and proportions of species represented in shell assemblages that are distinctive of particular stretches of coastline. Other remains of spatially restricted fauna and flora, as well as raw materials, would have comparable utility, and identifying these spatial markers could be the subject of future research on Santa Cruz Island.

\section{ACKNOWLEDGments}

Funding for the fieldwork at the 2 sites and for aspects of data analysis came from a grant from the Academic Senate Council on Research at the University of California, Santa Barbara (UCSB). I appreciate the efforts of Allison Jaqua and Craig Smith, who did the bulk of the excavation at the 2 sites within a tight field schedule. Lyndal Laughrin, Director of the Santa Cruz Island Reserve, and his staff provided logistical support during the fieldwork. I am especially grateful for the diligent efforts of 19 undergraduate students enrolled in a series of laboratory practicum courses who helped to process the collections at UCSB. Helping me to supervise their work was my able laboratory assistant, Brenda Gomez. Finally, I am grateful for the useful comments of an anonymous peer reviewer on an earlier draft of this paper, which helped me clarify and refine some of my arguments.

\section{Literature Cited}

BaLlantyne, K.E. 2006. An analysis of buried archaeological sites on western Santa Cruz Island. Master's thesis, Department of Anthropology, University of California, Santa Barbara, CA.

BinforD, L.R. 1980. Willow smoke and dogs' tails: huntergatherer settlement systems and archaeological site formation. American Antiquity 45:4-20.

Blanchette, C.A., B.R. Broitman, and S.D. Gaines. 2006. Intertidal community structure and oceanographic patterns around Santa Cruz Island, CA, USA. Marine Biology 149:689-701.

BRAjE, T.J. 2010. Modern oceans, ancient sites, archaeology and marine conservation on San Miguel Island, California. University of Utah Press, Salt Lake City, UT.

Braje, T.J., D.J. Kennett, J.M. Erlandson, and B.J. CulLETON. 2007. Human impacts on nearshore shellfish taxa: a 7,000 year record from Santa Rosa Island, California. American Antiquity 72:735-756.

Braje, T.J., T.C. Rick, and J.M. Erlandson. 2012. A trans-Holocene historical ecological record of shellfish harvesting on California's northern Channel Islands. Quaternary International 264:109-120.

Braje, T.J., T.C. Rick, L.M. Willis, and J.M. ErLandSON. 2011. Shellfish and the Chumash: marine invertebrates and complex hunter-gatherers on late Holocene San Miguel Island, California. North American Archaeologist 32:267-290.

BRUMBaCh, H.J., AND R. JaRVENPA. 1997. Ethnoarchaeology of subsistence space and gender: a subarctic Dene case. American Antiquity 62:414-436.

Campbell, B., and T.J. Braje. 2015. Estimating California mussel (Mytilus californianus) size from hinge fragments: a methodological application in historical ecology. Journal of Archaeological Science 58: $167-174$.

Culleton, B.J., D.J. Kennett, and T.L. Jones. 2009. Oxygen isotope seasonality in a temperate estuarine shell midden: a case study from CA-ALA-17 on the San Francisco Bay, California. Journal of Archaeological Science 36:1354-1363.

Gamble, L.H. 2017. Feasting, ritual practices, social memory, and persistent places: new interpretations of shell mounds in southern California. American Antiquity 82:427-451.

GILL, K.M. 2014. Seasons of change: using seasonal morphological changes in Brodiaea corms to determine season of harvest from archaeological remains. American Antiquity 79:638-654.

GILL, K.M. 2015. Ancient plant use and the importance of geophytes among the Island Chumash of Santa Cruz Island, California. Doctoral dissertation, Department of Anthropology, University of California, Santa Barbara, CA.

GLassow, M.A. 1992. The relative dietary importance of marine foods through time in western Santa Barbara County. Pages 115-128 in T.L. Jones, editor, Essays on the prehistory of maritime California. Publication 10, Center for Archaeological Research at Davis, University of California, Davis, CA.

GLassow, M.A. 1993. The occurrence of red abalone shells in northern Channel Island archaeological middens. Pages 567-576 in F.G. Hochberg, editor, Third California Islands Symposium: recent advances in research on the California islands. Santa Barbara Museum of Natural History, Santa Barbara, CA.

GLASSOW, M.A. 2005. Variation in marine fauna utilization by middle Holocene occupants of Santa Cruz Island. Pages 23-34 in D.K. Garcelon and C.A. Schwemm, editors, Proceedings of the Sixth California Islands Symposium, National Park Service Technical Publication CHIS-05-01. Institute for Wildlife Studies, Arcata, CA.

GLassow, M.A. 2014. Prehistoric occupation of the interior of western Santa Cruz Island. Monographs of the Western North American Naturalist 7:118-128.

GLassow, M.A. 2015. Red abalone middens on Santa Cruz Island, California: chronology and evidence of emergent complexity. American Antiquity 80:745-759.

Glassow, M.A., D.J. Kennett, J.P. Kennett, and L.R. WiLCoXon. 1994. Confirmation of middle Holocene ocean cooling inferred from stable isotopic analysis of prehistoric shells from Santa Cruz Island, California. Pages 223-232 in W.L. Halvorson and G.J. Maender, editors, The Fourth California Islands Symposium: update on the status of resources. Santa Barbara Museum of Natural History, Santa Barbara, CA.

Glassow, M.A., J.E. Perry, and P.F. Paige. 2008. The Punta Arena site: early and middle Holocene cultural development on Santa Cruz Island. Santa Barbara Museum of Natural History Contributions in 
Anthropology 3. Santa Barbara Museum of Natural History, Santa Barbara, CA.

Glassow, M.A., E.A. Sutton, C. Flores Fernandez, and H.B. Thakar. 2016. Proxy measurements of California mussel valve lengths. Advances in Archaeological Practice 4:31-40.

Glassow, M.A., H.B. ThaKaR, and D.J. Kennett. 2012. Red abalone collecting and marine water temperature during the middle Holocene occupation of Santa Cruz Island, California. Journal of Archaeological Science 39:2574-2582.

Hamilton, D.J. 1992. A method for reconstruction of zebra mussel (Dreissena polymorpha) length from shell fragments. Canadian Journal of Zoology 70: 2486-2490.

Jazwa, C.S., T.J. Braje, J.M. Erlandson, and D.J. KenNETT. 2015. Central place foraging and shellfish processing on California's northern Channel Islands. Journal of Anthropological Archaeology 40:33-47.

Jew, N.P., J.M. ERlandson, T.C. Rick, and L. REederMyERs. 2014. Oxygen isotope analysis of California mussel shells: seasonality and human sedentism at an 8,200-year-old shell midden on Santa Rosa Island. Archaeological and Anthropological Sciences 6:293-303.

Jones, T.L., D.J. Kennett, J.P. Kennett, And B.F. CoDDING. 2008. Seasonal stability in late Holocene shellfish harvesting on the central California coast. Journal of Archaeological Science 35:2286-2294.

KennetT, D.J. 2005. The Island Chumash, behavioral ecology of a maritime society. University of California Press, Berkeley, CA.
PERRY, J.E. 2005. Early period resource use on eastern Santa Cruz Island. Pages 43-53 in D.K. Garcelon and C.A. Schwemm, editors, Proceedings of the Sixth California Islands Symposium. National Park Service Technical Publication CHIS-05-01. Institute for Wildlife Studies, Arcata, CA.

Perry, J.E., AND K.M. Hoppa. 2012. Subtidal shellfish exploitation on the California Channel Islands: wavy top (Lithopoma undosum) in the middle Holocene. Pages 65-86 in M.A. Glassow and T.L. Joslin, editors, Exploring methods of faunal analysis: insights from California archaeology. Cotsen Institute of Archaeology, University of California, Los Angeles, CA.

STEWARD, J.H. 1938. Basin-Plateau aboriginal sociopolitical groups. Smithsonian Institution, Bureau of American Ethnology Bulletin 120. Government Printing Office, Washington DC.

Thakar, H.B. 2014. Food and fertility in prehistoric California: a case-study of risk-reducing behavior and population growth from Santa Cruz Island, California. Doctoral dissertation, Department of Anthropology, University of California, Santa Barbara, CA.

Thakar, H.B., M.A. Glassow, and C. Blanchette. 2017. Reconsidering evidence of human impacts: implications of within-site variation of growth rates in Mytilus californianus along tidal gradients. Quaternary International 427:151-159.

Received 4 January 2017

Revised 12 January 2018

Accepted 26 January 2018

Published online 13 September 2018 